7. Mahmut B, Ahmet B, Ahmet K, Akçay F, Selçuk SA. Serum D(-)lactate and nitric oxide (NO) levels in acute intestinal ischemia. Tr J Med Sci 1999;29:37-40.

DOI https://doi.org/10.30525/978-9934-26-075-9-28

\title{
FEATURES OF ECHO-CARDIOGRAPHIC INDICATORS \\ OF THE LEFT VENTRICLE IN ELDERLY WOMEN PATIENTS \\ WITH STABLE ANGINES WITH AND WITHOUT \\ COMORBIDBOID TYPE II DIABETES MELLITUS
}

\author{
Khapitska O. P. \\ Candidate of Medical Sciences, \\ Associate Professor at the Department of Internal medicine № 3, \\ National Pirogov Memorial Medical University \\ Sarafyniuk L. A. \\ Doctor of Biological Sciences, Professor, \\ Head of the Department of Physical training, \\ National Pirogov Memorial Medical University \\ Merculova D. $O$. \\ Assistant at the Department of Propedeutics \\ of Pediatric Diseases with Patient Care \\ National Pirogov Memorial Medical University \\ Shinkaruk-Dykovytska M. M. \\ Doctor of Medical Sciences, Professor, \\ Head of the Therapeutic Dentistry Department, \\ National Pirogov Memorial Medical University \\ Vinnytsya, Ukraine
}

Relevance: Coronary heart disease (CHD) is one of the most serious diseases of the cardiovascular system, with a high risk of cardiovascular disorders and even death [1, p. 193]. Ischemic heart disease is a leading cause of disability and mortality in economically developed countries [2, p. 92] and, as a result, remains one of the most pressing medical and socio-economic problems of modern society [3, p. 938]. Scientists have become increasingly 
interested in the problems and standards of treatment of concomitant diseases. Ischemic heart disease often develops in patients with type 2 diabetes mellitus, which serves as an independent risk factor for cardiovascular complications, as well as a possible trigger for the development of a number of cardiovascular diseases [4, p. 94]. Therefore, the study of changes in the cardiovascular system and the relationship with changes in carbohydrate and lipid composition of the blood in elderly women with stable angina with comorbid diabetes mellitus type 2 is an urgent problem and requires more in-depth study.

The aim of the study: To study the features of echocardiographic parameters in elderly women with stable angina compared with patients with stable angina with comorbid diabetes mellitus type 2 .

Materials and methods: clinical - for the general characteristic of patients groups, echocardiographic - for establishment of sizes features of the heart chambers and thickness of its walls and studying of a functional condition indicators of work heart; Doppler echocardiographic - for analysis of the transmitral flow curve and characteristics of diastolic function of the left ventricle; mathematical - for statistical processing of the obtained results. 66 sick women were examined Group I (patients with stable angina) included 31 women with a mean age of $63.23 \pm 2.02$ years, experience of stable angina $9.84 \pm 3.96$ years. Group II (patients with stable angina with comorbid type 2 diabetes) included 35 women with a mean age of $62.37 \pm 4.75$ years, experience of stable angina $-10.4 \pm 5.63$ years, diabetes $-13.5 \pm 6.8$ years. The control group included 28 healthy women aged on average (64.4 \pm 1.8$)$ years, by age they corresponded to patients with stable angina of the 1st and 2nd groups.

The study was conducted on the basis of the research laboratory of functional morphology and genetics of development (certificate of certification №003 / 10 from 11.01.2010) of the research center of National Pirogov Memorial Medical University, Vinnytsya.

Results: We found significant changes in intracardiac hemodynamics of the left ventricle in patients with stable angina, burdened and unburdened by type 2 diabetes. Thus, in healthy women the thickness of the myocardium of the interventricular septum is significantly less than in patients with stable angina without diabetes $(\mathrm{p}<0,001)$ and with comorbid type 2 diabetes ( $p<0,001$ ), between groups of patients in the value of this indicator statistically significant differences were not found.

The thickness of the myocardium left ventricle posterior wall undergoes significant changes in patients with heart failure. We found in the group of women with stable angina without diabetes the highest values of this indicator among all groups, recorded a significant increase $(p<0.001)$ compared with 
healthy individuals and patients with stable angina with diabetes $(\mathrm{p}<0.05)$. Type 2 diabetes mellitus on the background of stable angina also contributes to severe left ventricular hypertrophy, because the thickness of the posterior wall myocardium in patients with stable angina with diabetes is greater $(p<0.05)$ than in the control group.

We found that in women of the control group the final diastolic size of the left ventricle was significantly smaller than in patients with stable angina without diabetes and with comorbid type 2 diabetes (in both cases $\mathrm{p}<0.05$ ). Between both groups of patients the value of this indicator is not significant (p>0,05).

The final systolic size of the left ventricle is significantly larger in patients with stable angina than in the control, the largest values of this size were found in people with diabetes. Statistically significant differences were found between all comparison groups ( $\mathrm{p}<0.05-0.001$ ).

We found that in people with angina, along with an increase in morphometric echocardiographic size, there is an rising in the calculated parameters, in particular the relative wall thickness of the left ventricle and the mass of the left ventricular myocardium. Thus, in patients with stable angina without diabetes $(\mathrm{p}<0.01)$ and with comorbid type 2 diabetes $(\mathrm{p}<0.05)$ compared with the control group, there was a significant increase in the relative wall thickness of the left ventricle. While between groups of sick women the difference in the value of this indicator is minimal ( $>$ > 0.05). An increase in the relative wall thickness of more than 0.42 indicated concentric changes in the left ventricle, other words, a significant increase in wall thickness relative to the size of its cavity, which we found in the group of patients with stable angina.

We found that the mass of the left ventricular myocardium in patients with stable angina without diabetes was significantly $(\mathrm{p}<0.01)$ greater $(1.6$ times) than in healthy women. And in patients with stable angina with comorbid type 2 diabetes, this massometric index is 2 times higher $(p<0.001)$ than in the control and 1.26 times $(\mathrm{p}<0.05)$ compared with patients with stable angina without diabetes.

Conclusions: Thus, in patients with stable angina there is a morphometric remodeling of the heart, which is primarily manifested by changes in the geometry of the left heart, especially the echocardiographic size of the left ventricle. Comorbidity of coronary heart disease with type 2 diabetes leads to more pronounced changes in echocardiographic parameters of the left ventricle. 


\title{
References:
}

1. Гуревич М. А. Хронічна ішемічна (коронарна) хвороба серця. Москва, 2003. 192 с.

2. Серцево-судинні захворювання. Класифікація, стандарти діагностики та лікування / За ред. В. М. Коваленка. Київ: Моріон, 2018. $223 \mathrm{c}$.

3. Денесюк B.I., Денесюк О.В. Доказова внутрішня медицина: Підручник для студентів вищих медичних навчальних закладів III-IV рівнів акредитації. Вінниця: ДП «Державна картографічна фабрика», 2011. $928 \mathrm{c}$.

4. Волков В. І. Гендерні та вікові особливості ішемічної хвороби серця. Здоров'я Украӥни. 2007. № 12. Ч 1. С. 33-35.

DOI https://doi.org/10.30525/978-9934-26-075-9-29

\section{CURRENT UNDERSTANDING OF THE ACUTE KIDNEY INJURY PATHOGENESIS IN PATIENTS WITH COVID-19}

\author{
Khmelnov D. V. \\ $M D$, \\ Bilotserkivska station emergency medical care \\ Bila Tserkva, Kyiv region, Ukraine \\ Nykula B. T. \\ $M D$, \\ Kyiv Clinical Hospital on Railways Transport № 2 \\ Health Centre of JSC "Ukrainian railways" \\ Kyiv, Ukraine \\ Yelizarova O. T. \\ MD, Candidate of Medical Sciences, \\ Leading researcher of the Department of Public Health \\ SI «O.M. MarzeIev Institute for Public Health of the National Academy \\ of Medical Science of Ukraine» \\ Kyiv, Ukraine
}

Chronic Kidney Disease is one of the leading causes of Noncommunicable Diseases mortality [1, c.16]. An equally significant problem is Acute Kidney Injury (AKI) and, according to the WHO, about 4 million 